\title{
Evaluation of the Physical-Mechanical Properties of Type IV Gypsum
}

\section{Avaliação das Propriedades Físico-Mecânicas de Gessos Odontológicos Tipo IV}

\author{
Mariana Elias Queiroz*a; Juliana dos Santos Proença ${ }^{\mathrm{b}}$; Edwin Fernando Ruiz Contreras ${ }^{\mathrm{c}}$
}

\begin{abstract}
aState University Paulista Júlio de Mesquita Filho, Faculty of Dentistry of Araçatuba, Stricto Sensu Graduate Program in Dental Prosthesis. SP, Brazil.

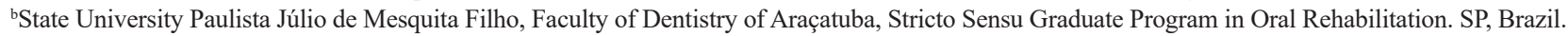
'State University of Londrina, Dentistry Course. PR, Brazil.

*E-mail: mariana.equeiroz@gmail.com

Recebido em: 31/08/2020

Aprovado em: 21/01/2021
\end{abstract}

\begin{abstract}
The purpose of this study was to evaluate a physical property (surface roughness) and a mechanical property (microhardness) of four type IV gypsum. 40 specimens were prepared from a metal matrix that reproduced an edentate upper alveolar ridge. They were divided into 4 groups (n = 10 Clone (G3), Durone(G4), SSWhite (G2), Asfer (G1) and submitted to roughness and microhardness tests . The obtained data were submitted to statistical analysis. By the Kolmogorov-Smirnov test it was verified that there was non-parametric distribution of the samples. The non-parametric Kruskal-Wallis and Mann-Whitney-U tests were applied in hardness and roughness data. In microhardness group 3(Clone) presented the best values (103.0 HV). In surface roughness (Ra), group 3(Clone) and Group 2 (SSWhite) showed the lowest values (1.8 $\mu$ m) and all evaluated groups presented higher values than those found in metallic matrix (baseline). It was concluded that gypsum models obtained from molds with irreversible hydrocolloid are rougher than molded surface, regardless of the commercial brand. The samples made with the Clone gypsum (G3) have the highest microhardness.
\end{abstract}

Keywords: Calcium Sulfate. Hardness. Dental Materials.

\section{Resumo}

O objetivo desse trabalho foi avaliar uma propriedade fisica (rugosidade superficial) e uma propriedade mecânica (microdureza) de quatro marcas comerciais de gesso tipo IV. Foram confeccionados 40 corpos de prova a partir de uma matriz metálica que reproduzia um rebordo alveolar superior edentado. Os mesmos foram divididos em 4 grupos $(n=10)$, de acordo com as marcas comerciais (Clone, Durone, SSWhite, Asfer), e submetidos aos testes de rugosidade e microdureza superficial utilizando um rugosímetro e um microdurômetro respectivamente. Os dados obtidos foram computados e submetidos à análise estatística. Pelo teste de Kolmogorov-Smirnov verificou-se que não houve distribuição Normal das amostras. Dessa forma foram aplicados os testes não paramétricos de Kruskal-Wallis e Mann-Whitney-U em ambas as análises. Na microdureza, a marca comercial Clone apresentou os melhores valores (103,0). Já na rugosidade superficial as marcas comerciais Clone e SSWhite apresentaram os menores valores $(1,8)$. Ainda em relação à rugosidade superficial, as marcas comerciais avaliadas apresentaram valores maiores que os encontrados na matriz metálica. Concluiu-se que modelos em gesso obtidos a partir de moldes com hidrocolóide irreversivel apresentam-se mais rugosos que a superficie moldada, independente da marca comercial avaliada. Os modelos em gesso confeccionados com a marca Clone apresentam melhor microdureza superficial.

Palavras-chave: Sulfato de Cálcio. Dureza. Materiais Dentários.

\section{Introduction}

In dentistry, clinical and laboratory procedures, such as confection of orthodontic devices and dental prosthesis, depend on the use of dental gypsum. Its use is very important and assists both prosthetics and surgeons in several stages of a treatment, from the diagnosis to a restoration or a prosthesis.

There are several types of gypsum products with different properties and purposes. Type I Gypsum or Gypsum for Molding was used in the final molding of total dentures. Type II gypsum is mainly used in the filling of muffles. Stone Gypsum or type III is used in the manufacture of models for total dentures because of greater resistance when compared to type I and $\mathrm{II}^{1}$. Type IV gypsum presents low-expansion, high-strength and is mainly used to fabricate models for fixed partial prostheses. The type $\mathrm{V}$ is a high-expansion and highstrength gypsum also used for making models. ${ }^{2}$ All these types of plaster have basically the same chemical composition which is Calcium Sulfate Hemihydrate, differing only in the size and shape of the particles according to the manufacturing process..$^{3-6}$

Some gypsum properties are essential for satisfactory final work because they can directly interfere with their performance. ${ }^{2,7}$ The ideal qualities for the plaster to be used as dental models include high surface hardness, that is necessary for the material to resist abrasions and scratches, good reproducibility and low roughness to accurately reproduce the structures copied in the molding, and high compressive strength to avoid damage during the manipulation of the model. Also, the dimensional changes must be minimal during 
the material setting process, so that they do not affect the fit and the precision of the dental prosthesis. . $^{2,3,7,8}$

Since dental plasters as well as molding materials are directly related to the accuracy of many procedures, some researches has been carried out to evaluate the physical and mechanical properties of these materials, including microhardness and surface roughness. ${ }^{9-11}$ De Cesero et al. ${ }^{12}$ tested the surface roughness of three comercial type IV gypsum varying the storage time of the specimens in order to evaluate the surface quality of the plasters. They verified that time and trademark had a significant influence on the roughness. Paes-Junior et al. ${ }^{13}$ evaluated the influence of the mold / model position during the pre-casting phase of a type IV gypsum on the hardness and roughness. According to this study, the positioning of the mold and the model did not influence the surface roughness on the other hand it had a significant influence on surface hardness.

Proença et al. ${ }^{14}$ evaluated whether the mixture of gypsum powder with different types of water would influence on physical and mechanical properties of gypsum. According to the study the analysis of surface roughness did not show significant difference between the different types of water. Sudhakar et al. ${ }^{15}$ analyzed the effectiveness of different methods used to increase the surface hardness of dental gypsum using two comercial brands of gypsum type IV. It was verified that there was a significant difference in superficial hardness between the methods and comercial brands evaluated.

Type IV gypsum is widely used in dentistry mainly in the manufacture of fixed protheses, because it has mechanical properties, such as minimal setting expansion and compressive strength, which stand out when compared to other types of plaster. ${ }^{2,3,7}$ Considering the clinical importance of dental plaster properties, the aim of this study was to verify if different trademarks of gypsum type IV present different roughness and surface hardness values. The null hypotesis of this study is that different commercial brands of type IV gypsum will not show any difference in the values of surface roughness and surface hardness.

\section{Material and Methods}

\subsection{Preparation of test specimens}

Forty specimens of type IV gypsum were made from a metal matrix which reproduces a edentulous upper alveolar ridge with three points on its surface: a point in the anterior region, one in the right posterior region and one in the left posterior region (Figure 1). Using this matrix, individual trays were made in self-curing acrylic resin (JET Artigos Odontológicos Clássico Ltda, São Paulo, São Paulo, Brazil), which were used to make the molding of this same matrix. The molding was done with Hydrogun 5 alginate (Zhermack SpA, Badia Polesine-RO, IT), and manipulation was performed by the same operator. The water/powder ratio 1: 1 was used and a vigorous spatulation was carried out for 30 seconds according to the manufacturer's indication. The tray was filled with alginate and it was carefully positioned on the metal matrix until the final setting time of the material.

Figure 1- Metallic matrix used to make test pieces

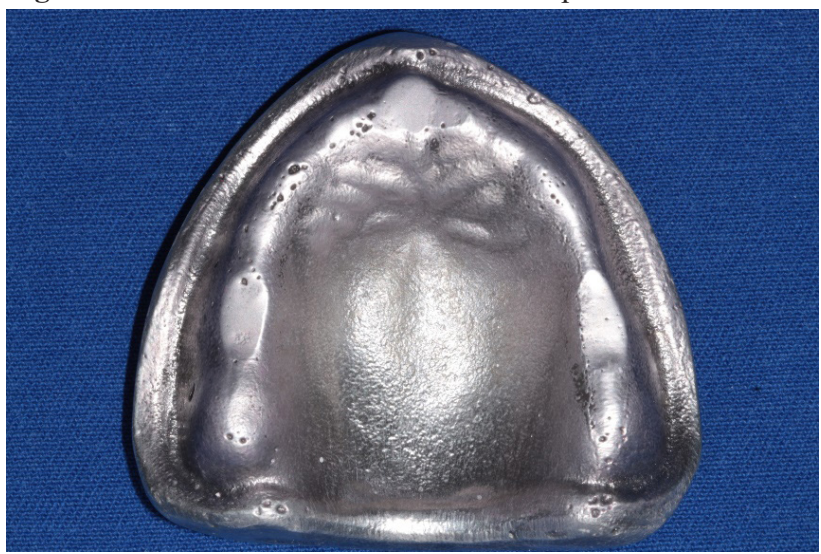

Source: The authors.

The type IV gypsum was weighed in a digital scale (Actlife, Balmak, Santa Bárbara d'Oeste, SP, Brazil) and the water dosed in a $20 \mathrm{~mL}$ syringe. The proportion and handling of the gypsums of each group followed the recommendations of manufacturer. The water and powder mixture was made by mechanical manipulation under vacuum (Polidental, Cotia, SP, Brazil) for 40 seconds. The plaster was cast on the alginate mold with a vibrator (VH Equipamentos Ltda, Araraquara, SP, Brazil). The models were desincluded from the mold after 40 minutes. The specimens were cut with the purpose of obtaining a straight base for greater stability during the tests of roughness and surface microhardness (Figure 2). They were divided into 4 groups $(\mathrm{n}=10)$ according to the brand of gypsum used in their manufacture: G1- Dent-Mix 4 (Asfer Industria Quimica Ltda, São Caetano do Sul, SP, Brazil), G2- G4 (S.S White Dentures Ltda, Rio de Janeiro, RJ, BR), G3- Clone (VIPI, Pirassununga, SP, Brazil) and G4- Durone (Dentsply, Petrópolis, RJ, Brazil).

Figura 2 - Test especimens

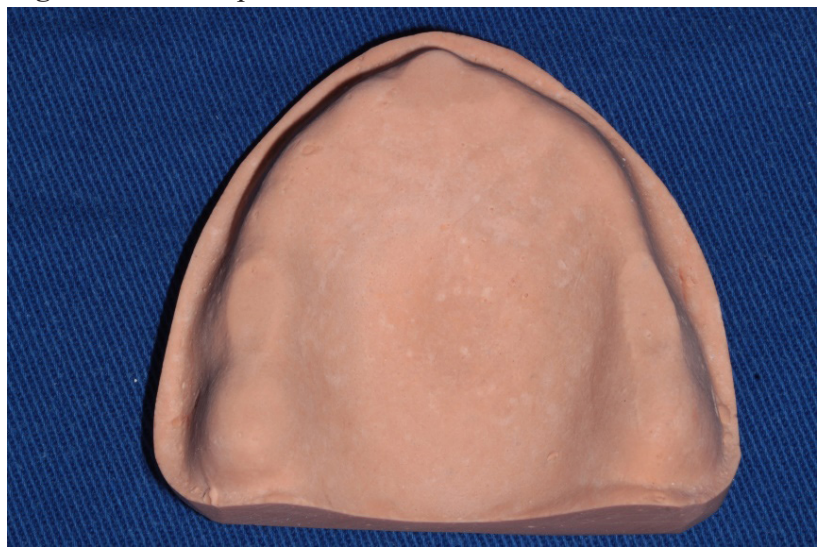

Source: The authors.

\subsection{Surface Roughness Test}

For the surface roughness test the specimens were fixed 
to a base to avoid movement during the test. The reading was performed by a rugosimeter (Mitutoyo Corporation SJ-400, Kawasaki, Kanagawa, Japan) and three measurements were made of each specimen equidistant $120^{\circ}$ each (Figure 3). A total of 9 measurements were performed on each test specimen, and the results obtained were submitted to statistical analysis. Also the roughness test of the metal matrix was performed, in order to obtain values for baseline. The closer values found in metal matrix, the higher the copy fidelity.

Figure 3 - Surface Roughness Test

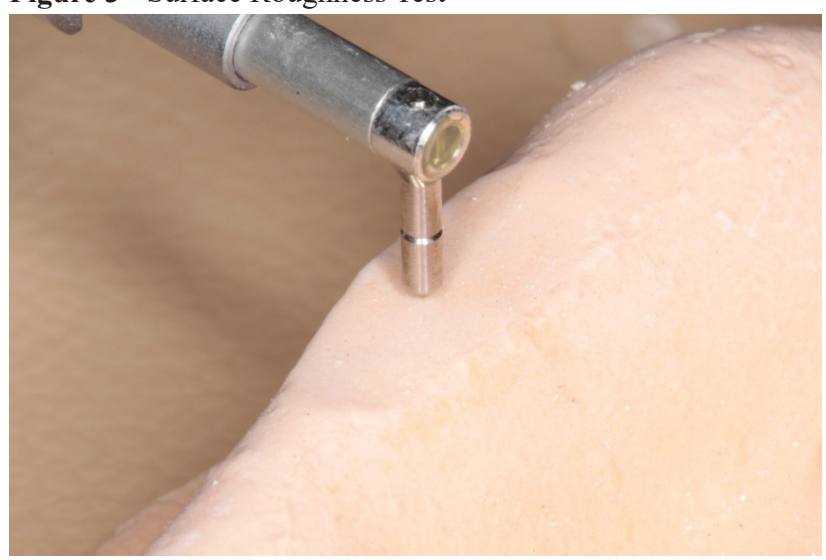

Source: The authors.

\subsection{Vickers Hardness Test}

The Vickers hardness test was performed by a Microdurometer (Mitutoyo Corporation HM-102, Kawasaki, Kanagawa, Japan) with a loading of $1 \mathrm{~N}$ for 15 seconds. ${ }^{16,17}$ In each specimen were made three edentations with a diamond tip with pyramid shape and square base. After edentation the two diagonals were measured in order to obtain the area of edentation (Figure 4).

Figure 4 - Vickers Hardness Test

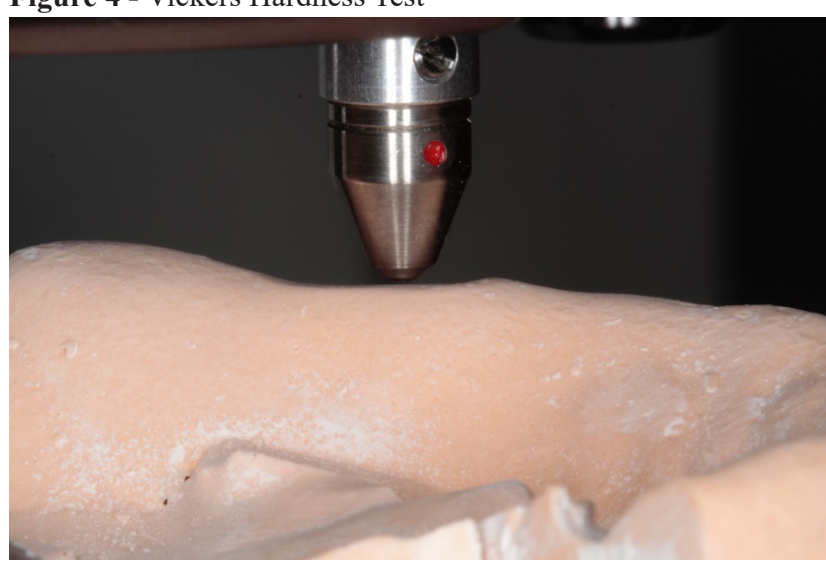

Source: The authors

\subsection{Statistical analysis}

The results were submitted to the Kolmogorov-Smirnov test whereby it was found that there was non-parametric distribution. Data from both tests were submitted to KruskalWallis test, which showed a significant difference in both groups. The post-hoc test Mann-Whitney-U was applied to verify which groups presented these differences.

\section{Results and Discussion}

In statistical analysis (Table 1) it can be verified that there is a difference between surface roughness of the tested groups with the G3 group (Clone) and G2 group ( SSWhite) presenting the lowest values. These groups did not show significant differences between them. On the other hand, the G4 (Durone) showed statistical difference of the other groups presenting the highest values of surface roughness. All the evaluated groups showed higher values of roughness to the value found in the metallic matrix $(1,45)$.

Table 1- Average surface roughness values

\begin{tabular}{|c|c|c|c|}
\hline Trade Mark & N & Média* & Desvio Padrão \\
\hline Durone & 90 & $2,3 \mathrm{c}$ &, 40 \\
\hline Clone & 90 & $1,8 \mathrm{ab}$ &, 32 \\
\hline SSWhite & 90 & $1,8 \mathrm{a}$ &, 40 \\
\hline Asfer & 90 & $1,9 \mathrm{~b}$ &, 39 \\
\hline Metallic Matrix & 01 & $1,45 \mathrm{~d}$ & 0 \\
\hline
\end{tabular}

Source: Research data.

The statistical analysis of microhardness (Table 2) also showed statistical difference between the tested groups. Group 3(Clone) was different from the other groups presenting the highest microhardness value (103.0 HV). However, G4 (Durone) and G2 (SSWhite) did not present statistical differences.

Table 2 - Average of Vickers Microhardness Test.

\begin{tabular}{|c|c|c|c|}
\hline Trade Mark & N & Média (VHN)* & Desvio Padrão \\
\hline Durone & 30 & $62,7 \mathrm{~b}$ & 18,9 \\
\hline Clone & 30 & $103,0 \mathrm{a}$ & 31,0 \\
\hline SSWhite & 30 & $59.4 \mathrm{~b}$ & 22,1 \\
\hline Asfer & 30 & $<17,0^{* *}$ & 0 \\
\hline
\end{tabular}

Source: Research data.

The null hypothesis of this study that different brands of type IV gypsum will not present different values of surface roughness and microhardness was rejected. Some previous studies have already demonstrated that different commercial brands of dental plaster show vaiations in some properties such as roughness and compression resistence. ${ }^{12,18}$

In the analysis of the surface roughness G3 (Clone) and G2 (SSWhite) had the lowest values $(1.8 \mu \mathrm{m})$, and also showed the closest value of the roughness of the metal matrix $(1.45 \mu \mathrm{m})$. The highest values were obtained from the G4 (Durone) $(2.3 \mu \mathrm{m})$. Roughness values were higher in this study due to the roughness of the metal matrix used (baseline). De Cesero et al. ${ }^{9}$ evaluated the surface roughness of different types of gypsum type IV in different storage times and found better performance on Durone brand in 1 hour $(0.3 \mu \mathrm{m})$ compared to the Tuff Rock in 1 day $(0.48 \mu \mathrm{m})$. Paes-Junior et al. ${ }^{13}$ verified the surface roughness of Durone by varying the mold / model position and obtained values between 0.743 and $0.677 \mu \mathrm{m}$ for surface roughness, different from those found in this study. This is due to the fact that the matrix used had a smoother 
surface and consequently its roughness value was lower than the metal matrix used in this study. Dias et al. ${ }^{19}$ evaluated the surface roughness of different types of gypsum and found no statistically difference between type IV and type V gypsum tested.

Farina et al. ${ }^{18}$ also evaluated the fidelity of dental gypsum using the surface roughness test. Among the gypsum evaluated, Durone type IV $(5.57 \mu \mathrm{m})$ and Exadur type V $(5.62 \mu \mathrm{m})$ presented lower copy fidelity when comparing roughness values with the metallic matrix $(6,12 \mu \mathrm{m})$. In the present study, Durone type IV also presented the roughness values more distant from the baseline, but with surface roughness values higher than the matrix.

Some studies have been developed in order to improve the properties of dental gypsum such as surface roughness, by adding some substances to the plaster. Cesero et al. ${ }^{20}$ analyzed the surface roughness of two trademarks of type IV gypsum, including the Durone brand. The analyzes were carried out in models made only by gypsum and models that in addition to gypsum received nanoparticles of silica. The authors stated that the surface roughness was statistically lower when these particles were added to the plaster. According to the authors, this improvement in surface roughness is due to the fact that these silica nanoparticles are deposited between the gypsum particles in the spaces left by water absorption.

On microhardness analysis Clone (103,0VHN) presented the highest value in comparison to Durone $(62,7 \mathrm{VHN})$ and SSWhite $(59,4 \mathrm{VHN})$. Farina et al. ${ }^{18}$ evaluated the Rockwell hardness of dental gypsum and found that Fujirock $(56,82 \mathrm{HR})$ presented the best results compared to Durone $(53,46 \mathrm{HR})$. Duke et al. ${ }^{21}$ compared the Knoop hardness of three new resinmodified gypsum materials and two conventional type IV gypsums (Silky-Rock, Die-Stone). The Die-Stone presented the best values of superficial hardness compared to the other gypsums tested.

In order to verify if there is an improvement in the dental plaster properties, some studies have been done adding some fillers to his material. In a study developed by Hamdy ${ }^{7} 15$ wt. $\%$ aluminum oxide fillers was added to the dental plaster used to make the specimens, and some properties were evaluated, including microhardness. The reinforced specimens showed higher microhardness values $(114.3 \mathrm{VHN})$ when compared to conventional plaster groups $(63.5 \mathrm{VHN})$. According to the author this can be attributed to the stregthening effect of aluminum oxide ceramic fillers, in addition to the decrease in plaster products that can lead to a drecrease in porosity.

Another factor to be considered is the material used to make the impression of the area of interest. Although widely used in dental offices, the alginate is a material with limited dimensional stability due to the processes of syneresis and imbibition suffered by it. ${ }^{22,23}$ In addition, trapping air or porosity within the impression material can influence the accuracy of the impression itself and the resulting model ${ }^{22}$ However, some studies have shown that Hydrogum 5 (Zhermack SpA, Badia
Polesine-RO, IT), alginate used for molding in this study, is a material that shows good dimensional stability, being a material capable of preserving more water. ${ }^{23,24}$

\section{Conclusion}

Models in gypsum obtained from molds with irreversible hydrocolloid appear rougher than the molded surface regardless of commercial Type IV gypsum evaluated. The plaster models made with Clone gypsum presented the best values of surface hardness.

\section{References}

1. Anusavice KJ Phillip's dental materials. Rio de Janeiro: Guanabara Koogan; 1998.

2. Akkus B, Demir N, Muhammet K, Yazman S. Compressive and diametral tensil strength of dental stone with $\mathrm{SiO}_{2}$ and $\mathrm{Al}_{2} \mathrm{O}_{3}$ nanoparticles. Int J Med Sci Innov Res 2018;3(5):13947.

3. Hamdy TM, Abdelnabi A, Abdelraourf RM. Reinforced dental plaster with low setting expansion and enhanced microhardness. Bull Nat Res Centre 2020;44(78):1-7. doi: https://doi.org/10.1186/s42269-020-00334-8

4. Kati FA, Yassin IN, Razak WA. Effect of adding some additives and drying method on compressive strength of gypsum products. Tikrit J Dent Scie 2017;5:25-32.

5. Subhan R, Pervaiz K, Malik S, Choudhry Z. The effect of diverse water type on the water powder ratio of various dental gypsum products. Pakistan Oral Dent J 2016;36(2):331-4.

6. Lindquist TJ, Stanford CM, Mostafavi H, Xie XJ. Abrasion resistance of a resin-impregnated type IV gypsum in comparison to convencional products. J Prosthet Dent 2002;87(3):319-22. doi: 10.1067/mpr.2002.122015

7. Hamdy TM. Effect of aluminum oxide addition of compressive strength, microhardness and setting expansion of dental plaster. Int J Adv Res 2019;7(9):652-7. doi: http:// dx.doi.org/10.21474/IJARD01/9711

8. Kenyon BJ, Hagge MS, Leknius C, Daniels WC, Weed ST Dimensional accuracy of 7 die materials. J Prosthodont 2005;14(1):25-31. doi: 10.1111/j.1532-849X.2005.00007x

9. Azer VA, Kerby RE, Knobloch LA. Effect of mixing methods on the physical properties of dental stones. J Dent 2008; 36:736-44. doi: 10.1016/j.jdent.2008.05.010.

10. Harris PE, Hoyes S, Lindquist TJ, Stanford CM. Alterations of surface hardness with gypsum die hardeners. J Prosthetic Dent 2004;92(1):35-8. doi: https://doi.org/10.1016/j. prosdent.2004.04.002

11. Fernandes CP, Vassilakos N. Accuracy, detail reproduction, and hardness of gypsum casts produced from silicone impressions treated with glow discharge. J Prosthetic Dent 1993;70:457-64. doi: https://doi.org/10/1016/00223913(93)90085-3

12. De Cesero L, Mota EG, Burnett LH, Spohr AM. The influence of postpouring time on the roughness, compressive strength, and diametric tensile strength of dental stone. J Prosthetic Dent 2014;112(6):1574-7. doi: 10.1016/j.prosdent.2013.07.032.

13. Paes-Junior TJA, Maegi B, Tango RN, Nascimento WF, Borges ALF, Kimpara ET. Propriedades do gesso tipo IV em função da variação no posicionamento molde/modelo durante a fase de presa. RGO 2010;58(1):65-9. 
14. Proença JS, Suzuki MM, Costa SC, Hirata BS, Lopes MB, Contreras EFR. Influence of different water types on the physical and mechanical properties of gypsum. Braz J Oral Scie 2015;14(3):199-203. doi: https://doi.org/10.1590/1677$3225 \mathrm{v} 14 \mathrm{n} 3 \mathrm{a} 05$

15. Sudhakar A, Srivatsa G, Shetty R, Rajeswari CL, Manvi S. Evaluation of the various drying methods on surface hardness of type IV dental stone. J Int Oral Health 2015;(6):103-106.

16. Li J, Kut IA, Hermansson L. High-stregth dental gypsum prepared by cold isostatic pressing. Biomaterials 1993;14(15):1186-7.

17. Marquezan M, Jurach EM, Guimarães VD, Valentim RGA, Nojima LI, Nojima MCG. Does the contact time of alginate with plaster cast influence its properties? Braz Oral Res 2012:26(3):197-201.

18. Farina AP, Festuccia MSCC, Nantes BS, Garcia LFR, Bezzon OL, Souza FCPP. Avaliação e comparação de propriedades físicas e mecânicas de gessos comerciais e experimentais. Rev Clín Pesq Odontol 2009;5(3):255-61.

19. Dias SC, Panzeri H, Ávila GB, Moyses MR, Reis AC, Agnelli JAM. Rugosidade de diferentes tipos de gesso e dois tipos de resina epóxica utilizados como materiais de vazamento e análise de compatibilidade das resinas com materiais de moldagem. Rev Odontol UNESP 2007;36(1):1-8.

20. De Cesero L, Oliveira EMN, Burnett Junior LH, Papaléo RM, Mota EG. The addition of sílica nanoparticles on the mechanical properties of dental stone. J Prosthetic Dent 2017;118(4):535-9. doi: https://doi.org/10.1016/j. prosdent.2017.01.001

21. Duke P, Moore K, Haug SP, Andres KJ. Study of the physical properties of type IV gypsum, resin-containing, and epoxy die materials. J Prosthetic Dent 2000;83:466-73. doi: https://doi. org/10.1016/S0022-3913(00)70043-6

22. Culhaoglu AK, Zaimoglu A, Dogan E, Ozkir SE. The influence of different mixing methods on the dimensional stability and surface detail reproduction of two different brands of irreversible hydrocolloids. Euro J General Dent 2014;3(1):17-21. doi: 10.4103/2278-9626.126204.

23. Aalaei S, Ganj-Khanloo R, Gholami F. Effect of storage period on dimensional stability of Algiplus and Hydrogum 5. J Dent (Tehran) 2017:14(1):31-9.

24. Sedda M, Casarotto A, Raustia A, Borracchini A. Effect of storage time on the accuracy of casts made from different irreversible hydrocolloids. J Contemp Dent Practice 2008;9(4):1-12. 